\title{
АНАЛІЗ ПРАКТИКИ ФОРМУВАННЯ І ФУНКЦІОНУВАННЯ ПІШОХІДНИХ ПРОСТОРІВ У МІСТАХ УКРАЇНИ
}

\section{ANALYSIS OF THE PRACTICE OF FORMATION AND FUNCTIONING OF PEDESTRIAN SPACES IN THE CITIES OF UKRAINE}

Осетрін М.М., к.т.н. професор кафедри міське будівництво; Петруня О.М., асистент кафедри міське будівництво (Київський національний університет будівництва і архітектури, Київ, Україна)

\author{
Osetrin M.M., PhD professor the Department of Urban Development; \\ Petrunya O.M., s. at the Department of Urban Development (Kyiv National \\ University of Construction and Architecture, Kyiv, Ukraine)
}

В статті представлений аналіз практики формування $i$ функиіонування пішохідних просторів в містах Украӥни. Були розглянуті проекти з реконструкиї пішохідних просторів в містах Киї, Одеса, Івано-Франківськ, Львів, Чернівиі, Чернігів та ін. Метою створення пішохідного простору $є$ необхідність раціонального перерозподілу території та впорядкування руху транспортних засобів для підвищення рівня безпеки руху пішоходів в містах.

In the modern period on the territory of Ukraine there are significant changes in the processes of urban pedestrian space development. Trends in urban design and analysis of domestic experience show that the pedestrian space with a high level of quality redistribution of the territory determines the formation of calm and safe urban environment and increases the tourist attractiveness. The article considers the analysis of the practice of formation and functioning of pedestrian space in the cities of Ukraine. There were considered the projects of pedestrian space reconstruction in the cities of Ivano-Frankivsk, Lviv, Chernivtsi, etc. The purpose of creating the pedestrian space is the need for rational redistribution of territory and streamlining of vehicles to increase the safety level of pedestrians in the cities. Pedestrian space is a naturally formed or artificially designed, unified living environment. It is a cultural, multidimensional, functional, aesthetic object, the organization of which is determined by social requirements. It is designed for people to move freely to the places of work, study, service and recreation in a designated area where the movement of motor vehicles is prohibited (except for special service vehicles, utilities and vehicles for people with disability). The article analyzes new approaches to the design of pedestrian spaces in different cities of Ukraine. When developing reconstruction projects and new pedestrian spaces, the diagrammatic statistical surveys of territories are conducted. Since each city is unique and has an individual architectural character, it makes impossible to have the one organized "model of improving the existing pedestrian space." As a result of the 
conducted researches, the basic principles of the organization of pedestrian space in the cities of Ukraine have been formed.

According to the Laws of Ukraine "On Road Traffic", "On Automobile Roads (Highways)", "About Local Self-Government in Ukraine", corresponding to the decisions of city commissions on road safety - executive committees of city councils of Ukraine develop schemes of master plans of the cities taking into account the conditions of safe and reliable pedestrian mobility.

Ключові слова: пішохідний простір, міста Украӥни, життєве середовище, формування пішохідних просторів.

Key words: pedestrian space, cities of Ukraine, living environment, formation of pedestrian spaces.

Постановка проблеми. Пішохідний простір - це природньо сформоване або штучно сплановане, уніфіковане життєве середовище. Це культурний, багатомірний, функціональний, естетичний об'єкт, організація якого визначається соціальними вимогами. Він призначений для вільного пересування населення до місць праці, навчання, об'єктів обслуговування та відпочинку по виділеній території, на якій заборонений рух на моторизованих транспортних засобах (за вийнятком автомобілів спецслужб, комунальної техніки та транспортних засобів для інвалідів) [1].

Головна мета. Метою створення пішохідного простору $\epsilon$ необхідність раціонального перерозподілу території, впорядкування руху транспортних засобів для підвищення рівня безпеки руху пішоходів в містах. Простори привабливі для прогулянок пішоходів, мають комфортні умови руху для формування спокійного та безпечного оточуючого міського середовища, спрямовані на підвищення туристичної привабливості.

Завдання дослідження: розкрити зміст поняття пішохідного простору, надати огляд сучасних теоретичних підходів до проектування, провести аналіз практики формування i функціонування пішохідних просторів в містах України.

Виклад основного матеріалу. Певний інтерес щодо практики проектування, формування та фукціонування пішохідних просторів представляє закордонний досвід. На основі статистичного опитування, найбільш пішохідними в країнах Свропи визначені міста - Вашингтон, Нью-Йорк і Бостон. Найменш пішохідними є: Тампа, Фенікс і Орландо. В містах Франції пішохідні території поділяються на класи: клас ТА переважно пішохідні простори; ТВ - переважно пішохідні простори, але допускається рух обслуговуючого транспорту; ТС - пішохідні, 3 можливістю руху обслуговуючого і пасажирського транспорту.

Сучасна світова практика часто вражає своїми інноваційними підходами. Одним із таких прикладів є розміщений на висоті 10 м від 
поверхні землі, на території надземної залізниці, пішохідний простір ХайЛайн (The High Line) на Манхетені [2].
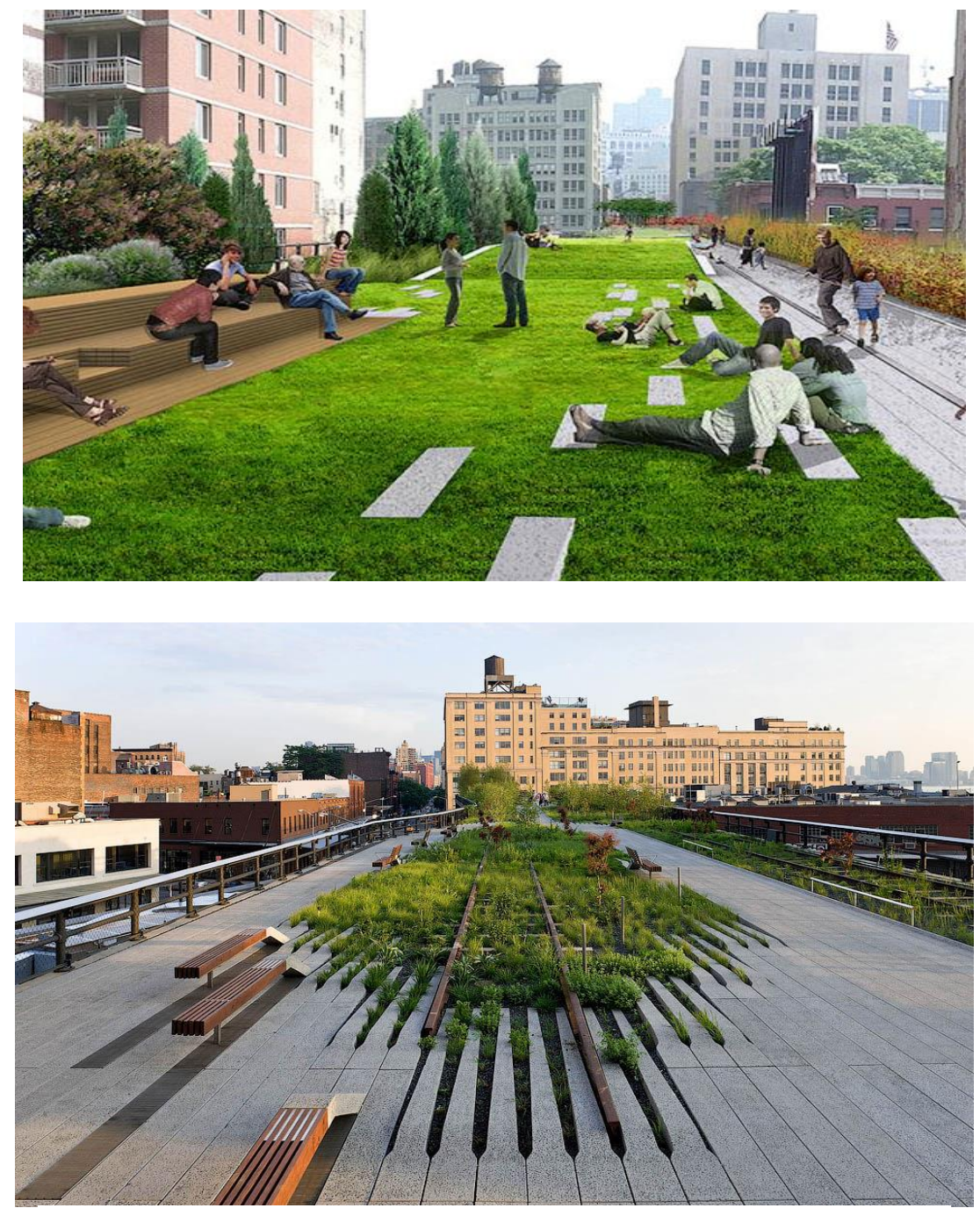

Рис. 1, 2. Пішохідний простір Хай-Лайн (The High Line) на Манхетені

В Україні перші пішохідні зони створювалися у 1960-х роках. В період 1980-х років були створені пішохідні вулиці у містах Київ, Берегове, Мукачево, Ужгороді, Виноградові, Львові, Одесі. Формувались пішохідні зони в Івано-Франківську, Луцьку, Тернополі. 
В сучасний період на території України відбуваються значні зміни в процесах розвитку пішохідних просторів в містах. Формуються нові підходи до проектування даних об'єктів в містобудуванні та архітектурі.

На Закарпатті практика пішохідних вулиць має давню історію. В містах існують території, виділені для пішохідного руху і називаються "корзо", що в перекладі з італійської мови означає «місце для прогулянок» [3]. В 2017 році в Івано-Франківську була створена пішохідна зона в історичному центрі міста в межах вулиць Галицька, Станіславська, Тринітарська, Шеремети, Старозамкова, Страчених Націоналістів, Вірменська, Труша, площі Ринок та майдану Шептицького, розроблена 3 урахуванням принципів універсального дизайну. Цінністю в сучасному урбанізованому просторі є доступ до води, тому популярні місця для відпочинку часто концентруються уздовж річок або озер. Набережна у Тернополі стала прикладом формування подібного пішохідного середовища. У 2018 році проект отримав гран-прі всеукраїнського конкурсу архітектури та урбаністики Ukrainian Urban Awards [4]. Сьогодні в Україні майже всі міста мають пішохідні простори. Особливо це характерно для туристичних міст типу Львів, Чернівці, Ужгород, Коломия та ін.

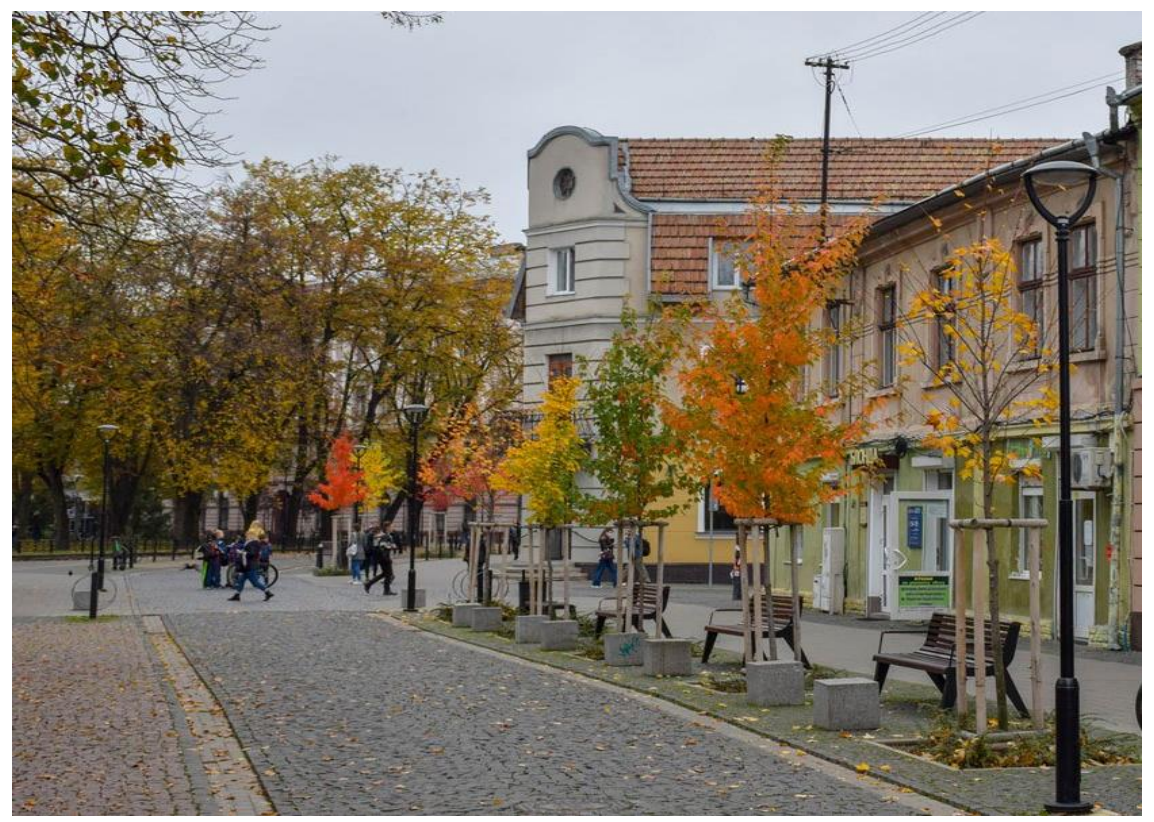

Рис.3. Пішохідна зона в історичному центрі міста Івано-Франківськ 
У Львові пішохідні простори існують у формі окремих фрагментарних ділянок, що не являють собою цілісну взаємопов'язану систему. У Львові такі території почали створювати в 2010 році. Вони поєднують 26 вулиць і площ в історичному центрі міста. В роки XIX - на початку XX ст. в забудові Львова виділяються риси архітектурного стилю - модерн або «сецесія», сформованого під впливом віденського «сеціону» [5]. Місто Львів також, як і більшість міст України, відходить від пострадянського мислення в контексті вуличного планування i проектування та обирає європейську практику. Спостерігається використання нових матеріалів і конструкцій, декоративних орнаментів, стилізованих рослинних мотивів та залізних решіток. Так звана сучасність у поєднанні з історично сформованими елементами у вигляді керамічних вставок та кольорових вітражів [6, 7].

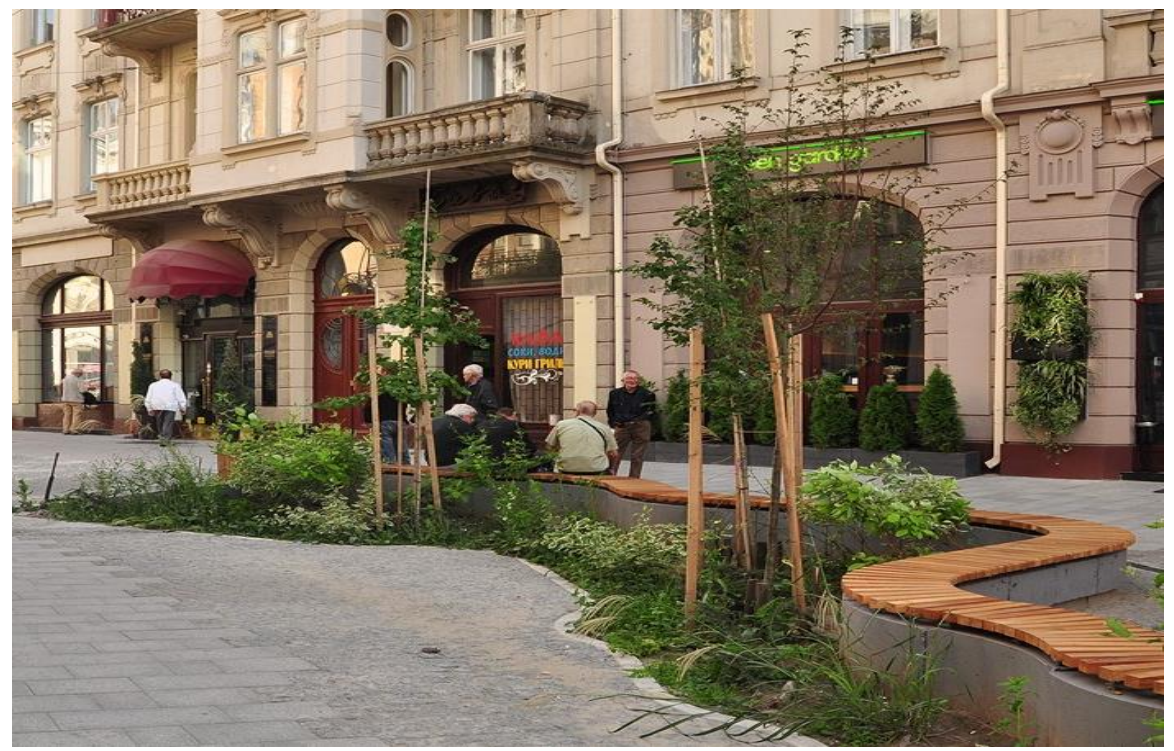

Рис.4. Пішохідний простір у місті Львів, 2021р.

Оскільки кожне місто $є$ унікальним i має індивідуальний архітектурний характер, то це унеможливлює існування однієї загальноорганізованої «моделі вдосконалення існуючого пішохідного простору». При розробці проектів реконструкції та створенні нових пішохідних просторів, проводились ситуаційні статистичні обстеження територій. На основі проведеного аналізу формування і функціонування пішохідних просторів в містах України, виділені певні види пішохідних просторів. 
Таким чином, даний простір сприймається як системный об'єкт і складається із 3-х категорій:

1. Простір - описує загальні фізичні характеристики об'єкту: за формою, розміром, планом і масштабом.

2. Поєднання і розміщення архітектурних, містобудівних об'ємів у просторі і часі - характеризує тип композиції даного пішохідного простору і поділяється на види: замкнений, напівзамкнений та відкритий

3. Об'ємно-просторова композиція у поєднанні із функціональним призначенням. Описує художній образ даного простору і має емоційний вплив на людину [8].

Висновки. Проаналізовані нові підходи щодо проектування пішохідних просторів у різних за величиною містах України свідчать про те, що практика користування простором радянського періоду себе вичерпала.

Тенденції містобудівного проектування, аналіз вітчизняного досвіду свідчить, що пішохідний простір з високим рівнем якісного життєвого середовища впливає на зниження рівня злочинності та кількості ДТП, сприяє розвитку позитивної соціальної активності на вулицях та веденню «здорового» способу життя. Такі простори привабливі для прогулянок i мають комфортні умови руху для пішоходів. Вони включають всі елементи, необхідні для сучасного міського життя, як функціональні потреби сьогоднішнього дня, так і духовні цінності, створені в минулому [9].

Керуючись Законами України «Про дорожній рух», «Про автомобільні дороги», «Про місцеве самоврядування в Україні», відповідно до прийнятих рішень міських комісії з безпеки дорожнього руху, виконавчі комітети міських рад міст України, розробляють схеми генеральних планів міст 3 урахуванням умов безпечної і надійної пішохідної мобільності для жителів [10].

У містобудівній практиці ідея багатофункціональності міського середовища вплинула на пошук нових підходів до формування пішохідних просторів містах України.

\section{References}

1. Valeev P. Peshekhodnye prostranstva gorodskih centrov / P. Valeev. Moskva Strojizdat 1983.

2. Arxytektura. Park XajLajn v NyuJorke. - FotoTelegraf. Yllyustryrovannыj ynternet-zhurnal o sobstyyax v myre. 2021. [Digital sourse] .- Access: https:// fototelegraf.ru) 
3. Novi pishoxidni vulyci Ivano-Frankivska. - Livejournal. - 2018. [Digital sourse] .- Access: https://alex-shutyuk.livejournal.com/502595.html

4. 15 najkrashhyx urbanistychnyx proyektiv desyatylittya. - K.: Kyyivskyj miskyj zhurnal «Xmarochos», 2020. [Digital sourse] -- Access: https://hmarochos.kiev.ua/2020/12/30/15-najkrashhyh-urbanistychnyh-proyektiv-desy atylittya-v-ukrayini/

5. Lemko I. 1243 vulici L'vova (1939-2009). - L'viv: Apriori, 2009. - S.98.

6. Turistichnij putivnik: L'viv. - L'viv: Centr Evropi, 2007. - S.171.

7. Novyny - Vulycya dlya vsix: chomu Lviv nazyvayut najuspishnishym u planuvanni vulychnogo seredovyshha. - Lviv: Instytut Prosvity, 2021. https://iprosvita.com

8. $\quad$ Linch K. Obraz goroda. / K. Linch. - M.: «Stojizdat», 1982. - $328 \mathrm{~s}$.

9. Petrunya O.M. Sposobi regulyuvannya ta vdoskonalennya bezpeki pishohidnogo ruhu u mistah. - K.: Mistobuduvannya ta teritorial'ne planuvannya". KNUBA, 2018. Vip. 68. S. 449-452.

10. DBN B.2.2-12:2018. Planuvannya i zabudova teritorij. - K.: Minregion Ukraïni, 2018. $-179 \mathrm{~s}$.

\section{Список використаної літератури}

1. Валеев П. Пешеходные пространства городских центров / П. Валеев. Москва Стройиздат 1983.

2. Архитектура. Парк Хай-Лайн в Нью-Йорке. - ФотоТелеграф. Иллюстрированный интернет-журнал о событиях в мире. 2021. [Електронний pecypc]. Режим доступу: https:// fototelegraf.ru)

3. Нові пішохідні вулиці Івано-Франківска. - LiveJournal. 2018/ [Електронний pecypc]. Режим доступу: https://alexshutyuk.livejournal.com/502595.html

4. 15 найкращих урбаністичних проєктів десятиліття. - К.: Київський міський журнал «Хмарочос», 2020. [Електронний ресурс]. Режим доступу: https://hmarochos.kiev.ua/2020/12/30/15-najkrashhyh-urbanistychnyh-proyektivdesyatylittya-v-ukrayini/

5. Лемко I. 1243 вулиці Львова (1939-2009). - Львів: Апріорі, 2009. - С.98.

6. Туристичний путівник: Львів. - Львів: Центр Європи, 2007. - С.171.

7. Новини - Вулиця для всіх: чому Львів називають найуспішнішим у плануванні вуличного середовища. - Львів: Інститут Просвіти, 2021. [Електронний pecypc] .- Режим доступу: https://iprosvita.com

8. Линч К. Образ города. / К. Линч. - М.: «Стойиздат», 1982. - 328 с.

9. Петруня О.М. Способи регулювання та вдосконалення безпеки пішохідного руху у містах. - К.: Містобудування та територіальне планування". КНУБА, 2018. Вип. 68. С. 449-452.

10. ДБН Б.2.2-12:2018. Планування і забудова територій. - К.: Мінрегіон України, 2018. -179 с. 